\title{
Pedagogias de medicalização do corpo na revista Veja
}

\author{
Michelle Pizzato Büker \\ Mestre em Educação pela ULBRA/RS \\ Professora adjunta do Curso de Psicologia da ULBRA/RS \\ Psicóloga concursada do Estado do RGS, atuando na Superintendência dos \\ Serviços Penitenciários pela Primeira Delegacia Penitenciária Regional \\ $\triangle$ ana.pereira@uerj.br
}

\section{Carin Klein}

Doutora em Educação pela UFRGS. Membro do Grupo de Estudos de Educação e Relações de Gênero (GEERGE) Professora do Programa de Pós-Graduação em Educação e do Curso de Pedagogia da ULBRA/RS

$\triangle$ ana.pereira@uerj.br

\section{Resumo:}

$\mathrm{O}$ artigo parte do interesse pela análise das pedagogias da medicalização do corpo veiculadas na revista Veja, compreendendo-a como instância pedagógica importante, no sentido de orientar e posicionar os sujeitos em relação aos ensinamentos ali divulgados. Ancoradas pela perspectivateórica dos Estudos Culturais e de autores/as que se aproximam da perspectiva pós-estruturalista, procuramos identificar e interrogar algumas discursividades veiculadas pelo discurso midiático, na medida em que atuam fortemente na produção de imperativos para os corpos, a fim de ensiná-los como se tornarem belos, magros e "saudáveis", mesmo que para isso seja necessário o consumo de medicamentos, suplementos, cosméticos ou cirurgias plásticas. Utilizou-se como metodologia de pesquisa a análise de reportagens, capas e materiais publicitários advindos da inserção de palavras chave no acervo digital da revista. Verifica-se a produção de processos de naturalização da medicalização como forma de prevenir e evitar, a qualquer custo, a gordura, o envelhecimento, a obesidade, a feiura e/ou os comportamentos que desviam do que se institui como no rma. As análises sugeremainda que aqueles que não conseguememagrecer ou cujos corpos se desviamdos padrões de uma normalidade utilitária estão fora do padrão, sendo vistos como os inábeis para cuidar de si, o que os faz despontar como as novas figuras de anormalidade. Obrigações e regras sobre como cuidar do corpo podem tornar-se imperativos, e a adesão (ou não) a eles pode servir como critério de avaliação do valor dos indivíduos no cenário contemporâneo.

Palavras-chave: Pedagogias da medicalização, Representação, Norma, Corpo, Revista Veja.

\section{Pedagogies of body medicalization in Veja magazine}

\begin{abstract}
:
This paper has derived fromthe interest in analyzing some pedagogies of body medicalization in Veja magazine, by understanding it as an important pedagogical means that has both guided and positioned subjects in relation to the teachings it conveys. Based on the theoretical perspective of the Cultural Studies and authors following the post-structuralist perspective, we have attempted to identify and question some discursivities spread by the media discourse, since they strongly act in the production of body imperatives to teach subjects to become beautiful, slimand "healthy", even if this
\end{abstract}


requires the use of medicines, supplements, cosmetics, or plastic surgeries. The research methodology used was the analysis of articles, covers and advertising materials resulting from the insertion of keywords in the digital collection of the magazine. There is the production of naturalization processes of medicalization as a way to prevent and avoid, at any cost, fat, aging, obesity, ugliness and / or behaviors that deviate from what is established as a norm. The analyzes also suggest that those who cannot lose weight or whose bodies deviate fromthe standards of utilitarian normality are out of the standard, being seen as unskillful to take care of themselves, which makes them emerge as the new figures of abnormality. Obligations and rules about body care can become imperative, and adherence (or not) to them can serve as a criterion for assessing the value of individuals in the contemporary setting.

Keywords: Medicalization Pedagogies, Representation, Standard, Body, Veja Magazine.

\section{Pedagogías de la medicalización del cuerpo en la revista Veja}

\section{Resumen:}

El presente artículo parte del interés por el análisis de las pedagogías de la medicalización del cuerpo vehiculadas en la revista Veja, comprendiéndolas como instancia pedagógica importante, en el sentido de orientar e posicionar a los sujeto en relación a las enseñanzas allí divulgadas. Ancladas por la perspectiva teórica de los Estudios Culturales y de autores que se aproximan a la perspectiva posestructuralista, buscamos identificar e interrogar algunas discursividades transmitidas por eldiscurso mediático, en la medida en que actúan fuertemente en la producción de imperativos para los cuerpos, con el fin de enseñarles sobre como tornarse bellos, delgados y "saludables", mismo que para eso sea necesario el uso de medicamentos, suplementos, cosméticos o cirugías plásticas. La metodología de investigación utilizada fue el análisis de artículos, portadas y materiales publicitarios resulta ntes de la inserción de palabras clave en la colección digital de la revista. Existe la producción de procesos de naturalización de medicalización como una forma de prevenir y evitar, a toda costa, la grasa, el envejecimiento, la obesidad, la fealdad y / o los comportamientos que se desvían de lo establecido como norma. Los análisis también sugieren que aquellos que no pueden perder peso o cuyos cuerpos se desvían de los estándares de la normalidad utilitaria están fuera del estándar, siendo vistos como incapaces de cuidarse, lo que los hace emerger como las nuevas figuras de anormalidad. Las obligaciones y reglas sobre el cuidado del cuerpo pueden volverse imperativas, y la adhesión (o no) a ellas puede servir como criterio para evaluar el valor de las personas en el entorno contemporáneo. Palabras clave: Pedagogías de la Medicalización, Representación, Norma, Cuerpo, Revista Veja.

\section{INTRODUÇÃO}

Este artigo $^{1}$ parte do interesse pela análise das pedagogias de medicalização do corpo veiculadas na revista Veja, compreendendo-a como instância pedagógica importante, no sentido de orientar e posicionar os sujeitos em relação aos ensinamentos ali divulgados. 0 propósito deste trabalho é problematizar de que forma o corpo é representado nesse artefato, além de verificar como os sujeitos - as mulheres em especial - são convocados e posicionados

\footnotetext{
${ }^{1} \mathrm{O}$ artigo é um recorte de uma dissertação de mestrado apresentada no ano de 2018, intitulada: Pedagogias midiáticas da medicalização do corpo na revista Veja.
} 
para cuidar da dieta, dos exercícios físicos e da aparência, necessitando assumir um número cada vez mais amplo de prescrições e imperativos contemporâneos.

Ancoradas pela perspectiva teórica dos Estudos Culturais e de autores/as que se aproximam da perspectiva pós-estruturalista, procuramos identificar e interrogar algumas discursividades veiculadas pelo discurso midiático, na medida em que atuam fortemente na produção de imperativos para os corpos, a fim de ensiná-los como se tornarem belos, magros e "saudáveis", mesmo que para isso seja necessário o uso de medicamentos, suplementos, cosméticos ou cirurgias plásticas.

A investigação mobiliza dois conceitos que, apesar de distintos, se articulam no processo de medicalização do corpo: as pedagogias culturais e a medicalização. A partir desses dois conceitos, optamos por nomear de "Pedagogias da Medicalização" o processo que será examinado e discutido aqui, bem como, por considerar que existem pedagogias culturais que interpelam os sujeitos e instituem processos de medicalização do corpo.

A abordagem desse tema resulta do momento atual vivenciado na contemporaneidade, no qual se é cercado pela disseminação de conteúdos, imagens, informações e conhecimentos. Andrade (2016) aborda que o conceito de pedagogias culturais se tornou possível nos últimos tempos em virtude das transformações sofridas pelos campos da pedagogia e da cultura. Camozzato (2014, p. 580) afirma que "parece admissível situar o conceito de pedagogias culturais como a expressão de um conjunto de transformações sociais e culturais que tornaram possível a sua emergência". A partir da sua aproximação com a Educação e com os Estudos Culturais, o conceito foi inserido dentro de uma rede de significações relacionadas à cultura, à política e ao poder, tornando-se uma ferramenta capaz de discutir e problematizar as relações entre artefatos da cultura, tal como a mídia, e processos educativos (ANDRADE; COSTA, 2015).

\section{A MEDICALIZAÇÃO DO CORPO}

Em meio às transformações contemporâneas, diversas formas de medicalização são experienciadas cotidianamente. Nas escolas, as crianças mais “agitadas" são reconhecidas, encaminhadas, diagnosticadas - e, possivelmente, medicadas - com hiperatividade ou déficit 
de atenção; nos jornais, são ensinadas estratégias para combater o envelhecimento com as últimas e mais modernas tecnologias dermatológicas; nas revistas, somos convocados/as a aprender como ter um corpo magro, "sarado", "curado", "são", "livre" de gorduras indesejáveis, mediante a incorporação de um estilo de vida mais "adequado" ${ }^{2}$. A isso, aliamse dietas alimentares, uso de suplementos polivitamínicos e uma rotina diária de exercícios físicos. Partimos do argumento de que, no bojo dessas divulgações midiáticas, está uma série de prescrições e ensinamentos para que os sujeitos venham a assumir determinadas posições, a fim de responsabilizarem-se por uma forma de viver mais "ordenada" e "equilibrada", produzindo-se, assim, imperativos de como ter e/ou conquistar um corpo "saudável".

Compreendemos que a busca por um corpo-modelo (ZAGO, 2013) se intensifica na contemporaneidade, a partir da proliferação das mídias, tornando o uso de medicamentos e/ou intervenções cirúrgicas, alternativas "rápidas", "baratas" e "acessíveis" a uma parcela da população tomada (e produzida) como insatisfeita em relação ao corpo. A "medicalização", descrita por alguns estudiosos como um processo pelo qual problemas não médicos passam a ser tratados como enfermidades e desordens (PETRINA, 2006; CONRAD, 2007; SCHUTZ e RIPOLL, 2013; SANTOS, 2014), surge como um sintoma contemporâneo. Conforme a definição de medicalização, publicada no Manifesto do fórum sobre medicalização da educação e da sociedade $(\mathrm{s} / \mathrm{d})$, o processo de medicalização produz e transforma questões não médicas em problemas médicos. Nesse sentido, dimensões de diferentes esferas da vida coletiva, social e/ou de ordem política são tomadas como problemas individuais e biológicos.

\begin{abstract}
Uma vez classificadas como 'doentes', as pessoas tornam-se 'pacientes' e consequentemente 'consumidoras' de tratamentos, terapias e medicamentos, que transformam o seu próprio corpo no alvo dos problemas que, na lógica medicalizante, deverão ser sanados individualmente. Muitas vezes, famílias, profissionais, autoridades, governantes e formuladores de políticas eximem-se de sua responsabilidade quanto às questões sociais: as pessoas é que têm 'problemas', são 'disfuncionais', 'não se adaptam', são ‘doentes' e são, até mesmo, judicializadas. (MANIFESTO... p. 1. s/d)
\end{abstract}

Vale ressaltar que esse processo de medicalização é vivenciado em todas as esferas da vida, pois há uma busca descomedida por esclarecimentos biológicos, fisiológicos e

\footnotetext{
${ }^{2}$ A adoção de um estilo de vida parece funcionar como "um conjunto mais ou menos integrado de práticas que um indivíduo abraça, não só porque essas práticas preenchem necessidades utilitárias, mas porque dão forma material a uma narrativa particular de autoidentidade" (GIDDENS, 2002, p. 79). O estilo de vida reflete as "supostas" escolhas dos indivíduos intercedidas pelo consumo e pelas promessas de um corpo perfeito e/ou saudável.
} 
comportamentais que possam dar conta dos diversos tipos de sofrimento e/ou de supostas “imperfeições", sejam elas relacionadas a dores físicas ou emocionais. Portanto, a medicalização parece atuar de forma imediata para tratar diversas dores e tem sido utilizada de forma descriminalizada, fazendo do Brasil um dos países que mais se automedicam no mundo. Conforme a Federação Nacional dos Farmacêuticos (2015), os índices de crescimento do setor farmacêutico no Brasil demonstram de forma inequívoca a forte expansão do consumo de medicamentos no país ${ }^{3}$.

Conrad (2007, p. 4) afirma que "o crescimento da jurisdição médica é uma das transformações mais potentes da última metade do século XX no Ocidente". O referido autor aponta que esse processo já vem sendo estudado - especialmente por sociólogos - desde os anos 1960, primeiramente, focalizando a chamada "medicalização do desvio"; neste rol, entrariam alcoolismo, transtornos mentais, vício de opiáceos, transtornos alimentares, transtornos sexuais e de gênero, disfunção sexual, dificuldades de aprendizagem, abuso infantil e sexual, entre outros. Além disso, cabe salientar que "comportamentos que uma vez foram definidos como imorais, pecaminosos ou criminosos foram ressignificados pela medicina, que os deslocou do campo da maldade para a doença" (CONRAD, 2007, p. 6). Segundo o autor, diversos processos vitais do cotidiano passam por essa ressignificação, devendo tornar-se alvo dos processos de medicalização, tal como a ansiedade, o humor, a menstruação, o controle da natalidade, o controle da fome, a infertilidade, a menopausa, o envelhecimento, etc. (CONRAD, 2007).

Para Conrad (2007), torna-se central compreender que:

[...] a chave para a medicalização é a definição. Ou seja, um problema é definido em termos médicos, descrito usando linguagem médica, entendido através da adoção de um quadro médico ou 'tratado' com uma intervenção médica [...]. Assim, podemos examinar a medicalização da epilepsia, uma desordem que a maioria das pessoas concorda ser 'realmente' médica, assim como podemos examinar a medicalização do alcoolismo, do transtorno de déficit de atenção e hiperatividade (TDAH), da menopausa ou da disfunção erétil [...]. O ponto principal na medicalização é entender que uma entidade que é considerada uma doença não é, por si só, um problema médico; em vez disso, ela precisa ser definida como um (CONRAD, 2007, p. 5-6).

\footnotetext{
${ }^{3}$ Estudos sobre a automedicação no Brasil explicam o elevado índice de consumo de medicamentos, que teria como causas a desinformação da população, propagandas exces sivas e indutoras do consumo, fiscalização sanitária deficiente e dificuldade de acesso às consultas médicas (PÚBLIO, 2015).
} 
A medicina, então, serve como um recurso para ampliar e operar outras lógicas de funcionamento do corpo na contemporaneidade: os saberes médicos são apropriados e transformados em saberes midiáticos e também em saberes empresariais, sob o estímulo e o olhar atento do "mercado da saúde". Para obter sucesso em suas vendas, as empresas de medicamentos e de diagnósticos, bem como as clínicas de emagrecimento, investem no marketing, obtendo maior faturamento e objetivando a criação de novos produtos e mercados. A seguir, abordamos a mídia como produtora de representações e sentidos sobre o corpo belo e saudável, aliada ao uso de medicamentos, e como reguladora de práticas de emagrecimento.

\section{A MÍDIA COMO REGULADORA DE PRÁTICAS CORPORAIS}

Abordar as pedagogias da medicalização focadas na produção e veiculação de representações ${ }^{4}$ de um corpo belo e saudável significa identificar e refletir sobre o que é prescrito e ensinado na mídia, uma vez que ela convoca os sujeitos a assumirem e a tomarem alguns imperativos como seus, associando o corpo magro com a saúde, por exemplo. Tendo em vista esse contexto, argumentamos que a revista Veja se torna um importante artefato da cultura, capaz de veicular e produzir tais prescrições. Refletir sobre os ensinamentos veiculados na cultura torna-se central na contemporaneidade, uma vez que somos enredados pela disseminação de conteúdos, imagens, informações e conhecimentos. É por meio da emergência do conceito de pedagogias culturais e da sua articulação com a cultura, a política e o poder, que o conceito opera como uma ferramenta importante no exame e na problematização das relações entre os artefatos da cultura e os processos educativos.

Camozzato (2014) investe na discussão sobre as pedagogias do presente e na argumentação de que há um processo de atualização constante para que os sujeitos conectem-se as exigências e necessidades que cada tempo impõe. Eles/as precisam aprender para levar "adiante [os ensinamentos] do mundo em que vivem, adaptando-se a ele" (CAMOZZATO, 2014, p. 575). Para isso, torna-se fundamental aderir ao que é ensinado na

\footnotetext{
${ }^{4}$ A representação "[...] inclui as práticas de significação e os processos simbólicos por meio dos quais os significados são produzidos, posicionando-nos como sujeito" (WOODWARD, 2007, p. 17). É mediante os significados produzidos por intermédio das representações que damos sentido à nos sa experiência e àquilo que nos tornamos.
} 
mídia, assim como, em tantas outras instâncias culturais: consumindo, atualizando-se, emagrecendo, cuidando-se, incorporando práticas e saberes, a fim de tornar-se sujeito de determinados discursos. A repercussão disso pode estar nos modos de controle e regulação das relações sociais, pois incitam os indivíduos "a implementarem sobre si uma série de pequenos movimentos, que mostram justamente a dispersão desse conceito num conjunto maior que a sociedade tem produzido". (CAMOZZATO, 2014, p. 575).

A partir do conceito, também é possível entender a mídia como uma instância pedagógica em que os saberes são construídos e veiculados em meio a relações de poder ${ }^{5}$. Isto é, a mídia atua (junto a outros artefatos) como pedagogia cultural, educando, disciplinando e regulando as condutas e medicalizando os corpos. Ela busca ensinar formas de ser e de relacionar-se no e com o mundo, tendo uma função fundamental na sustentação dos circuitos globais e de mercado, em articulação com os movimentos globais de informação, conhecimento e capital. A mídia atua, dessa forma, ampliando a velocidade e o alcance das informações, favorecendo a redução de fronteiras e de distâncias para reunir bens de consumo e lucros; com isso, tem impacto tanto nos sentidos atribuídos às coisas, quanto nos próprios modos de ser e de viver (HALL, 1997).

As revistas, de acordo com Costa (2012), têm servido como importantes materiais para a análise cultural $^{6}$, não apenas por tornarem-se uma forma de entretenimento, mas, sobretudo, por atuarem na constituição de representações e subjetividades contemporâneas. Segundo a autora, elas podem ser analisadas como produtos de uma determinada cultura, na medida em que "inspiram e orientam nossas escolhas, dirigindo-nos para este ou aquele caminho. Elas também constroem significados sobre o mundo, sobre as identidades, sobre nossas experiências e práticas" (COSTA, 2012, p. 4).

Fischer (1996; 1997), ao analisar programas de TV e matérias de revistas, especialmente da revista Capricho, assim como textos jornalísticos destinados ao público jovem, cita uma propaganda da Associação Nacional de Editores de Revistas (ANER), contida em uma edição da Revista Capricho. A autora evidencia como esses materiais se caracterizam

\footnotetext{
5 A partir de Michel Foucault (1997), compreendemos o poder em sua relação com a produção de saberes que atuam na constituição de sujeitos de determinados tipos. Além disso, trata-se de uma perspectiva que entende o poder como microfísico, descentralizado, horizontal e difuso.

${ }^{6}$ Para ler e ampliar esta discussão:ANDRADE, 2008; FISCHER, 1996; SCHWENGBER, 2006.
} 
por direcionar uma série de produtos a diferentes segmentos etários, econômicos, de gênero, etc., na constituição do que chamamos de público-alvo:

A maior prova de que o leitor de revista é um excelente consumidor é que ele já começa comprando a revista. E pela revista que ele compra você consegue saber exatamente quem ele é, o que pensa, do que ele precisa. É por isso que a revista é o meio que permite a melhor segmentação. Anunciando em revista você fala diretamente com o seu consumidor. Ou seja, aproveita cada centavo para atingir quem tem potencial para comprar. E para quê anunciar para quem não pode comprar, se o objetivo final da propaganda é vender? (FISCHER, 1996, apud REVISTA CAPRICHO, Nov. 94, p. 100-101).

Para Sarlo (1997, p. 25), a publicidade busca capturar-nos por meio de nossos desejos e do consumo, pois "somos livremente sonhados pelas capas de revista, a publicidade, a moda: cada um de nós encontra um fio que promete conduzir a algo profundamente pessoal, nessa trama tecida com desejos absolutamente comuns". Tais desejos são impulsionados pelos diferentes artefatos disponíveis na contemporaneidade: somos interpelados pela mídia, por intermédio de jornais, programas de TV, peças publicitárias, filmes, novelas, revistas, sites, canais de conteúdos.

Fischer (2001, p. 48-49) indica, em suas análises, que tais materiais produzem investimentos constantes e em transformação, na busca pela produção de desejos para tornarmo-nos e/ou reconhecermo-nos cada vez mais belos, jovens, magros e eternos. Desse modo,

[...] os imperativos da beleza, da juventude e da longevidade, sobretudo nos espaços dos diferentes meios de comunicação, perseguem-nos quase como tortura: corpos de tantos outros e outras nos são oferecidos como modelo para que operemos sobre nosso próprio corpo (FISCHER, 2001, p.48-49).

Conforme Bauman (2001), a maioria das pessoas busca exemplos, modelos de sucesso a seguir, pois é olhando para a experiência de outras pessoas que esperamos descobrir e localizar a causa de nossa própria in/felicidade e in/satisfação, buscando meios de resistir aos problemas e/ou de resolvê-los.

Sibilia (2002), ao tratar do fenômeno das selfies nas redes sociais e na internet, diz que nossas subjetividades estão se tornando cada vez mais epidérmicas, ou seja, é preciso que 
mostremos "na pele" tudo aquilo que "somos". Se nossas subjetividades são expressas na pele, de maneira a exteriorizar nossas identidades, também estão voltadas para o julgamento e a apreciação dos olhares alheios. Nessa nova dinâmica social da visibilidade, o corpo e as práticas de cultivo da beleza tornam-se centrais na contemporaneidade. A autora prossegue, dizendo que (2004, p. 68) "a visibilidade e o reconhecimento no olhar alheio são fundamentais na definição do que cada um é", e aprender a tornar o corpo uma bela imagem se torna tão importante quanto saber cuidar da saúde e da aparência do corpo orgânico. Pelas mídias, em especial na internet, não só se pode acessar a intimidade de outras pessoas, como ainda se torna possível produzir, editar e divulgar a própria vida em uma sucessão de narrativas autobiográficas e de sucesso.

Segundo Poli Neto e Caponi (2007), a sociedade contemporânea assiste ao desfile de "corpos perfeitos" ocupando centralidade na vida moderna. Tratamentos diversos no âmbito biomédico oferecem alternativas para embelezar os corpos e aproximá-los de uma vida saudável. Não somente são disponibilizados produtos para esse fim, como também são oferecidas soluções para quem não tem condições financeiras para realizar tais tratamentos, como parcelamento de cirurgias plásticas e consórcios médicos. Isso traz a possibilidade (ou a pretensão) de um "corpo perfeito" e acessível a uma porção cada vez maior de pessoas, penetrando em diferentes segmentos etários, econômicos, sociais e culturais.

É relevante refletir também sobre o investimento da mídia direcionado às mulheres, que são convocadas e posicionadas para cuidarem do corpo, da dieta, dos exercícios, da organização das rotinas, da pele, do marido, dos/as filhos/as, devendo assumir um número cada vez mais amplo de prescrições e imperativos contemporâneos. Nesta discussão, vale trazer o argumento de Klein e Vargas (2019) quando salientam que:

[...] um imperativo é aquilo que assume o valor de sentença, ordem, pedido ou obrigação. Algo também pode se tornar um imperativo à medida que é reforçado, replicado ou solicitado com tamanha insistência e em diferentes locais e instituições da cultura que se torna um dever, simbolicamente, a serviço de uma suposta demanda social, ética ou moralidade (KLEIN e VARGAS, 2019, p. 531).

Como já dissemos, os investimentos evidenciados na revista Veja estão voltados, fundamentalmente, para as mulheres, posicionadas e colocadas no centro dos processos educativos de medicalização e das estratégias publicitárias, para que sejam amplamente 
ensinadas a obterem um corpo saudável. Klein (2010, p. 35) indica que as análises de gênero não buscam "negar a materialidade dos corpos, mas rejeitar a noção de existência de qualquer sentido inato, preexistente ou universal que muitas vezes foi [e é] utilizado para explicar e/ou justificar determinadas diferenças e hierarquias sociais" relativas a homens e mulheres. Problematizar os processos de medicalização veiculados no âmbito da revista Veja, principalmente aqueles voltados às mulheres, significa suspeitar de conhecimentos e representações, tais como as que buscam produzir determinadas noções de saúde, cuidado, equilíbrio, beleza, etc. com o objetivo de nortear a vida de homens e mulheres, como se isso fosse algo inerente ao feminino ou ao masculino.

\section{AS IMAGENS ANALISADAS}

Para a realização das análises, de acordo com o recorte deste artigo, utilizamos como material empírico algumas capas e matérias, veiculadas pela revista Veja, nos anos de 1996, 1998, 2009, 2010, 2011 e 2015. Tais materiais resultam da inserção de palavras-chave no acervo digital da revista Veja, tendo como base a inserção das palavras separadamente: medicamento(s), remédio(s), fármaco(s), tratamento(s) e corpo(s); além das palavras-chave inseridas, todas as capas compreendidas entre os anos 1968 e 2018, mesmo que não tenham sido identificadas pelo mecanismo de busca, foram verificadas.

Tal funcionalidade possibilita ao assinante, mediante a realização de um cadastro e acesso por meio de um login, conferir todas as edições da revista, tornando-se possível folhear digitalmente as páginas, imprimi-las, fazer print da tela e buscas por meio de palavras-chave. Ao todo, trabalhamos com nove imagens nesta investigação, consideradas de maior potencial para a discussão da temática aqui explorada.

Esta abordagem resulta de um momento específico vivenciado na contemporaneidade, no qual se é cercado pela disseminação de determinados conteúdos, imagens, informações e conhecimentos. Imagens também podem ser tomadas e lidas como textos, difundindo informações e conhecimentos. Nesse sentido, as imagens que integram a revista Veja não são compreendidas simplesmente como elementos “[...] ilustrativos, mas como prática discursiva" cujo caráter pedagógico e produtivo pode ser explorado 
(SCHWENGBER, 2014, p. 264), ou seja, buscando-se compreender de que forma as imagens atuam na constituição de sujeitos contemporâneos.

Quadro 1 - Organização das imagens analisadas neste artigo.

\begin{tabular}{|c|c|c|}
\hline FIGURAS & MANCHETES DAS CAPAS & MATERIAIS E ANOS DE PUBLICAÇÃO \\
\hline Figura 1 & Gordura tem remédio. & Capa da Revista Veja, novembro de 1996. \\
\hline Figura 2 & Comer sem engordar!!! & Capa da Revista Veja, março de 1998. \\
\hline Figura 3 & $\begin{array}{l}\text { Emagrecer pode ser uma } \\
\text { delícia. }\end{array}$ & Capa da Revista Veja, maio de 2009. \\
\hline Figura 4 & O fim do efeito sanfona. & Capa da Revista Veja, fevereiro de 2010. \\
\hline Figura 5 & $\begin{array}{l}\text { As regras boas (e viáveis) da } \\
\text { nutrição sadia. }\end{array}$ & Capa da Revista Veja, novembro de 2010. \\
\hline Figuras 6 e 7 & $\begin{array}{c}\text { Parece Milagre e matéria } \\
\text { Menos sete, menos dez, menos } \\
\text { doze quilos }\end{array}$ & $\begin{array}{l}\text { Capa e matéria da Revista Veja, setembro } \\
\qquad \text { de } 2011 .\end{array}$ \\
\hline Figura 8 & Remédios para emagrecer. & Capa da Revista Veja, fevereiro de 2011. \\
\hline Figura 9 & Ovo Vitória final & Capa da Revista Veja, maio de 2015. \\
\hline
\end{tabular}

Fonte: Própria.

Os caminhos percorridos até aqui nos permitiram identificar que a produção desse material empírico se torna produtivo para o exame das representações e dos sentidos em torno dos processos de medicalização do corpo. Ademais, a análise cultural que nos propomos 
tem como objetivo "atentar para o modo como o discurso constrói, de forma sistemática, versões do mundo social [...] e para o modo como ele posiciona os indivíduos nas relações de poder" (WORTMANN, 2007, p. 84-85).

\section{MEDICALIZAÇÃO E EMAGRECIMENTO NA REVISTA VEJA}

A revista Veja, conforme a Editora Abril é considerada a maior e mais influente revista semanal de informação do Brasil, com circulação de 862 mil exemplares por semana. Em se tratando do público-alvo de leitores, aproximadamente 63\% têm entre 20 e 49 anos, sendo 53\% mulheres. A revista publica, em média, 10.500 páginas de anúncios por ano, o equivalente a 2,8\% do volume total dos investimentos em publicidade no Brasil. Sua divulgação conta com edição impressa e digital, a fim de disponibilizar seu conteúdo para a leitura no tablet ou smartphone. Nomeia-se como "A maior revista do país é também a mais relevante e faz uma curadoria do que acontece de mais importante no Brasil e no mundo para você entender mais, saber mais." (ASSINE..., 2020).

São numerosos os estudos acadêmicos sobre a revista Veja, nas mais variadas áreas do conhecimento, entre elas, pode-se citar estudos das áreas da comunicação, jornalismo, marketing, linguística e ciências políticas, sob as mais variadas perspectivas teóricas. Na área da educação e, especificamente, no campo dos Estudos Culturais, a revista já foi bastante estudada ${ }^{7}$.

Por ser uma revista de grande circulação nacional, possui ampla abrangência, fazendo circular reportagens, anúncios publicitários e informativos sobre as mais variadas áreas. Temas relacionados com a saúde são apresentados, principalmente, por meio de reportagens que a associam a modos de evitar e prevenir a obesidade.

No entanto, em tempos antigos, possuir formas arredondadas e proeminentes era desejo de muitos indivíduos, além de ser sinônimo de beleza, prosperidade e riqueza. Da

\footnotetext{
7 Para ampliar citamos as seguintes dissertações de mestrado: "A educação escolarizada nos discursos sobre o ensino fundamental de nove anos: Isto É, Veja a reinvenção da 'nova' escola nas revistas" (ROSA, 2008); "Discursos que educam representações das cotas raciais na Veja" (CRUZ, 2009); "A formação da infância do consumo: um estudo sobre crianças nos anúncios publicitários da Veja" (PONTE, 2010); "A cultura da performatividade: narrativas sobre Educação na revista Veja” (CUNHA, 2013) e “As representações do divórcio na Revista Veja -1977 e 2013”. (BORSA, 2015).
} 
mesma maneira, a magreza já esteve relacionada com miséria, escassez de alimentos e doenças (SANTANNA, 2016). Porém, conforme argumenta Stenzel (2003), em meados do século XIX, houve uma reconfiguração nos padrões de beleza, trazendo o entendimento de que a magreza teria relação com a beleza:

[...] o emagrecimento passou a ser um desejo e uma meta a ser cumprida, como representação de aceitação e prestígio: até 1890 o sucesso ou o reconhecimento se davam para aqueles que possuíam corpos avantajados; em 1900 esta representação se inverteu, e de lá para cá o sucesso e a beleza vêm sendo associados à magreza (STENZEL, 2003, p. 29).

Essa busca por um corpo definido e magro como sinônimo de saúde pode ser evidenciada na capa da revista Veja de 1996 (figura 1), onde se vê a imagem de um corpo feminino magro e esguio, envolto por cápsulas de medicamentos - tais cápsulas "pairam” ou mesmo "gravitam" em torno do corpo da mulher, vestida apenas com um maiô laranja cavado. A manchete "Gordura tem remédio - as novas drogas que combatem a obesidade", posicionada no canto inferior direito (e ao lado dos glúteos e das coxas da mulher), mostra o sentido preferencial de leitura, sentenciando: a gordura é uma doença e deve ser combatida a todo custo, inclusive com o uso de remédios.

Vale dizer que não buscamos desconsiderar a importância dos medicamentos em nossas vidas como estratégias para tratar e curar as doenças, porém, cabe identificar e analisar alguns processos educativos que têm atuado na naturalização do uso de medicamentos, associados tanto a um corpo magro, quanto a um estilo de vida saudável.

Pensar sobre as pedagogias da medicalização do corpo a partir de um artefato da cultura de grande circulação fomentou nossa capacidade analítica, principalmente, motivada pelos processos educativos que a mídia, em especial os veiculados na revista Veja, foram/são capazes de ensinar. 
Figura 1: Manchete "Gordura tem remédio".

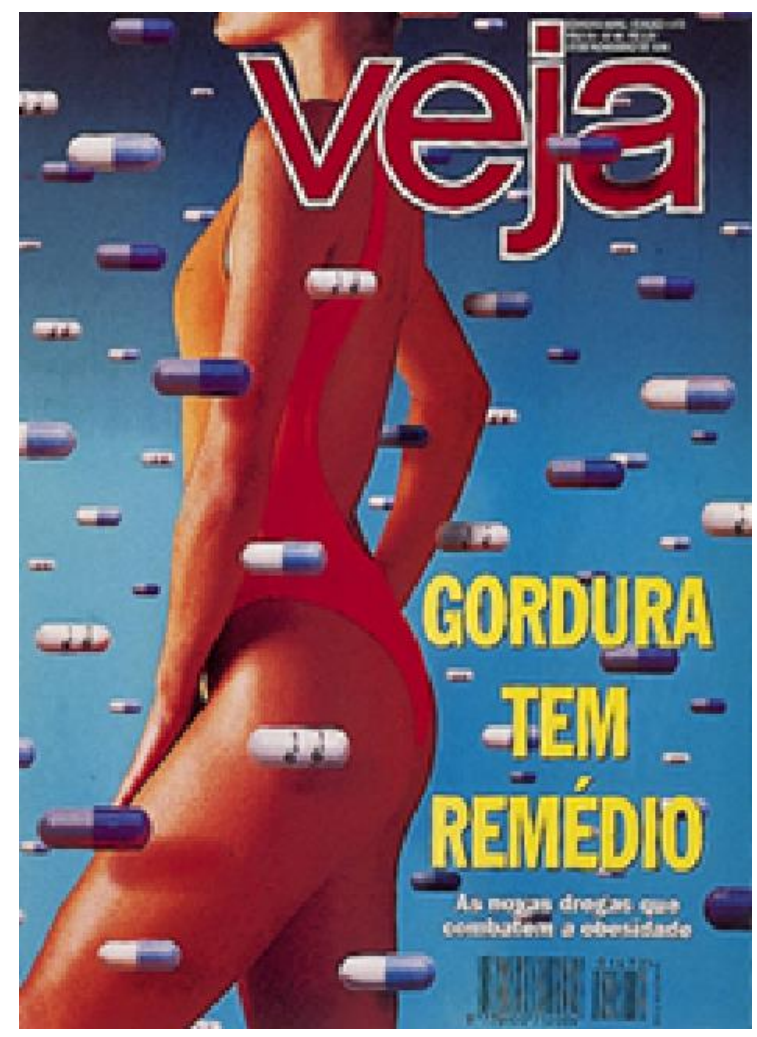

Legenda: Capa da Revista Veja, novembro de 1996.

Fonte: Acervo Digital Veja. Acesso mai.2017.

Fischler (2005), em seu artigo intitulado “Obeso benigno e obeso maligno”, fala sobre a ambivalência de ser gordo. O duplo estereótipo denota o gordo como alguém com facilidade para as relações interpessoais, sendo geralmente extrovertido, brincalhão e alegre, como uma espécie de compensação por um possível traço depressivo, aliado a sentimentos de egoísmo e/ou irresponsabilidade em relação ao (des)controle de si. A lipofobia, entendida como a rejeição maníaca à obesidade, amplia-se como uma característica da nossa época, em que a gordura se torna algo intolerável, cuja cura pode valer-se do uso de medicamentos, os quais, nesse contexto, não podem ser desconsiderados.

Importa lembrar que não somente questões relacionadas ao processo de saúde e doença são abordadas nas revistas. Percebe-se que as prescrições e os imperativos em torno da beleza e da magreza têm se constituído como formas de regulação e sujeição dos sujeitos, 
estando, portanto, centralmente associados à saúde e sendo fomentados pelas pedagogias da medicalização.

Dois anos após a publicação examinada acima, a revista apresenta um novo medicamento, "revolucionário", para o controle e a eliminação das gorduras (figura 2).

Figura 2: Manchete “Comer sem engordar!!!”.

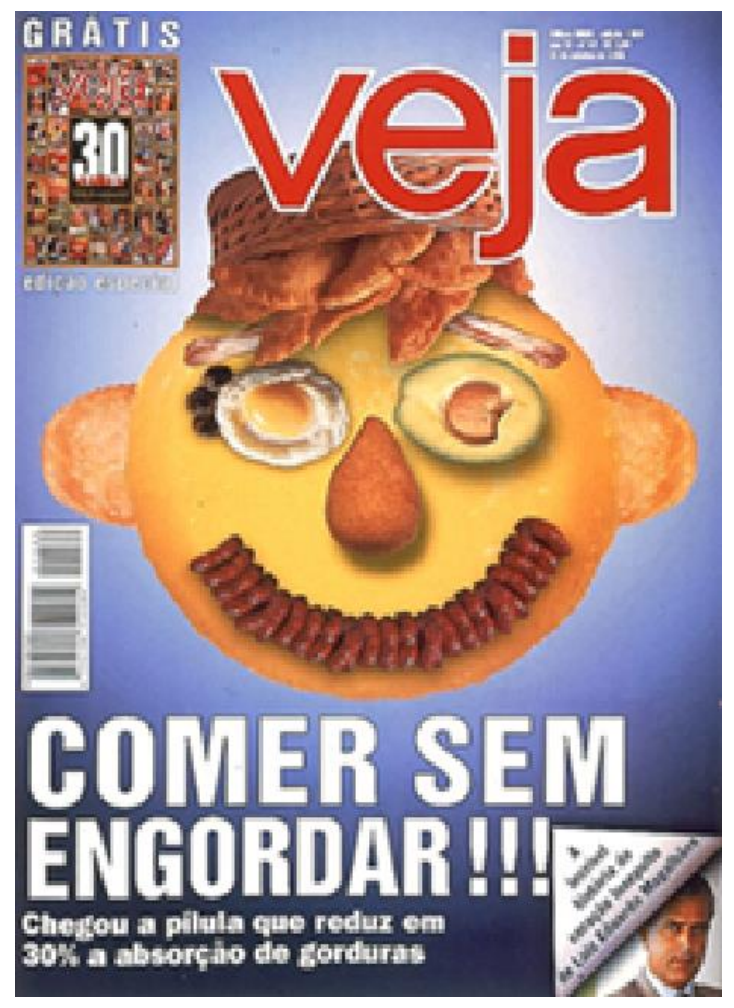

Legenda: Capa da Revista Veja, março de 1998.

Fonte: Acervo Digital Veja. Acesso mai.2017.

No centro da imagem, um rosto formado por comidas consideradas gordurosas, como ovo frito, abacate, coxinha, amêndoas, bacon e pastéis. $O$ rosto está sorridente, e a manchete, repleta de pontos de exclamações, diz: “Comer sem engordar!!!”, acompanhada da frase: "Chegou a pílula que reduz em 30\% a absorção de gorduras". Pode-se pensar que a demonstração de felicidade ali representada está diretamente ligada à possibilidade de consumo do Orlistat, composto químico principal do Xenical - controverso remédio para emagrecer que não atua no sistema nervoso central, e sim, no intestino, tendo a diarreia como efeito colateral principal. Mesmo com um efeito colateral desagradável, o medicamento é 
apresentado como uma promessa a quem deseja emagrecer sem deixar de comer os alimentos gordurosos apresentados na capa.

No que diz respeito à repulsa pelo corpo gordo, tal tema já fora pesquisado nos anos 60 em estudos de recepção, em que silhuetas de corpos magros e gordos foram mostradas a crianças. As silhuetas obesas foram classificadas pelas crianças como negativas, sendo associadas com características como "trapaceiro", "preguiçoso”, “sujo”, “mau”, "feio”. Já as silhuetas magras obtiveram associações positivas. $\mathrm{Na}$ grande maioria dos países desenvolvidos, os indivíduos sonham em ser magros, mas encontram-se obesos e sofrendo com essa contradição (FISCHLER, 2005).

\begin{abstract}
Como explicar tal contradição entre a simpatia aparentemente evocada pelos mais cheios de corpo e a recusa quase fóbica que parece se manifestar, hoje particularmente, contra a gordura? O que é verdadeiro? Amamos os gordos, ou os odiamos? Somos lipófilos ou lipófobos? [...] a corpulência traduz aos olhos de todos a parte da comida que nós nos atribuímos, isto é, simbolicamente, a parte que tomamos para nós, legitimamente ou não, na distribuição da riqueza social (FISCHLER, 2005, p.70).
\end{abstract}

Onze anos mais tarde, localizamos a capa da revista Veja de maio de 2009, que apresenta a imagem de uma mulher utilizando como roupa um vestido de couve chinesa, espécie de repolho de origem oriental utilizado como ingrediente para compor saladas, alimento típico de dietas (figura 3). A chamada pretende ensinar duplamente: a necessidade de ter um corpo belo e magro e o fato de que "emagrecer pode ser uma delícia" (VEJA, 2009).

A reportagem de maio de 2009 ainda traz um guia especial com dicas de dietas e um manual de alimentos saudáveis. De acordo com esses materiais, nosso corpo guarda os mecanismos que garantiriam a sobrevivência da espécie humana, há centenas de milhares de anos, por meio da estocagem de gordura; por isso, em alguma altura da vida, todos/as necessitam controlar a alimentação. 
Figura 3: Manchete "Emagrecer pode ser uma delícia”.

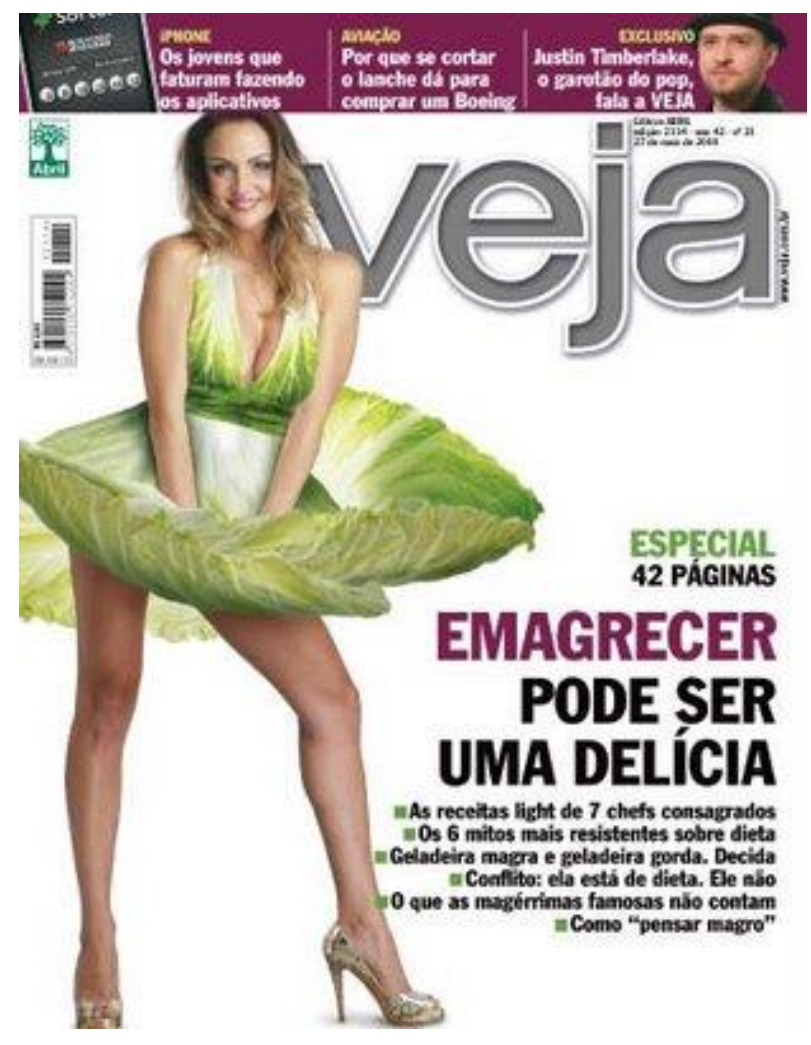

Legenda: Capa da Revista Veja, maio de 2009.

Fonte: Acervo Digital Veja. Acesso em mai.2017.

Nesse contexto, observamos o uso corriqueiro de palavras como "dicas", "guias" e "manuais", ou seja, termos que nos encaminham à reflexão sobre como são prescritos comportamentos e ações, a fim de alcançarmos um corpo saudável e idealizado, parecendo que basta seguir determinados passos, orientações ou fórmulas mágicas para que se cumpram, de forma utilitária e simplificada, os objetivos e ensinamentos em questão. Nesse sentido, Klein (2003) auxilia-nos a pensar que, atualmente, há uma proliferação do uso de guias, cartilhas e manuais, no âmbito das políticas públicas de inclusão social e/ou de educação e(m) saúde, por exemplo, considerando-se que, na sua definição, os termos revelam o caráter de "nortear, orientar, dirigir, governar" as condutas dos sujeitos. Trata-se de recursos cujo propósito está em multiplicar, disseminar e tornar efetivos os ensinamentos para que os sujeitos, alvos dessas pedagogias, se responsabilizem por eles e os incorporem.

Voltando à imagem da capa, fica evidente que ela faz menção à atriz, modelo e cantora norte-americana Marilyn Monroe, símbolo de beleza e sensualidade nos anos 50, imortalizada 
por suas curvas corporais e cabelos loiros. A conhecida imagem da atriz em que ela aparece com o vestido levantado pela corrente de ar de um duto de ventilação do metrô é utilizada pela revista como recurso retórico - uma mulher é retratada na mesma posição corporal, sugerindo a possibilidade de que todos/as alcancem a mesma saúde, leveza e sensualidade (figura 3).

Embora os padrões de beleza não sejam estáticos e transformem-se com o passar dos tempos, Marilyn Monroe parece persistir como um ícone atemporal. Ela se torna um símbolo permanente de sensualidade, mesmo na contemporaneidade, em que se observa a busca por um corpo magro como obrigação rigorosa, generalizada e ligada à saúde e à beleza. Para alcançar esse fim, multiplicam-se as "fórmulas" e as técnicas para a conquista do emagrecimento, com o intuito de modificar o corpo e modelar a silhueta. Reverberam em grande proporção na mídia intervenções, tais como: lipossucção, lipotomia, lipoescultura, lipodissolução - todas supostamente criadas para modelar a silhueta e torná-la mais afuselada (VIGARELLO, 2006).

Essa obrigação com o cuidado dos corpos, evidenciada por Vigarello (2006), passa a funcionar como um imperativo, sob o qual os corpos se tornam parâmetros ou critérios para mensurar e avaliar o valor dos indivíduos e dos grupos sociais. Conforme Guizzo (2011), características como força, rigidez, juventude, longevidade, saúde e beleza passam a ser critérios para avaliar o valor dos indivíduos, a fim de condicionar e regular suas condutas, pertencimentos e inserções. Com a veiculação e o acesso a inúmeras estratégias para a conquista de um corpo jovem, magro, belo e saudável, aqueles que não se vigiam, não se cuidam e não se controlam passam a fazer parte dos incapazes de cuidar de si.

Desse modo, os inábeis para cuidar de si indicam uma espécie de (re)atualização das representações da anormalidade: velhos/as, gordos/as, feios/as, sedentários/as, fumantes, bêbados/as, viciados/as, adictos/as, compulsivos/as, pessoas que vivem com deficiências, pessoas que vivem com HIV, anoréxicos/as, bulímicos/as, deprimidos/as, etc. A carne humana que não se coloca a serviço do capital financeiro, das grandes corporações, das instituições, nem dos ensinamentos multiplicados no âmbito da mídia, pode ser pensada como corpo que escapa a esse contínuo "dar forma”, tornando-se o desvio, a carne humana podre ou a carniça que necessita ser descartada (VASCONCELOS; ZAGO, 2015). 
A capa da revista Veja de fevereiro de 2010 expõe as seguintes expressões: "Os 10 mandamentos da manutenção do peso ideal" e "Os 5 pecados de quem não consegue ficar magro" (figura 4). Percebemos, ao longo das análises, a utilização e a incorporação de enunciados do discurso religioso no discurso midiático, a fim de produzir e ampliar sentidos ligados à magreza, como forma de interpelar os sujeitos e de aproximá-los da adesão e da conquista de um corpo saudável. O termo sacro "milagre" foi percebido em várias outras edições, ligado ao uso de expressões como "alma" e "santo".

Figura 4: Manchete "O fim do efeito sanfona".

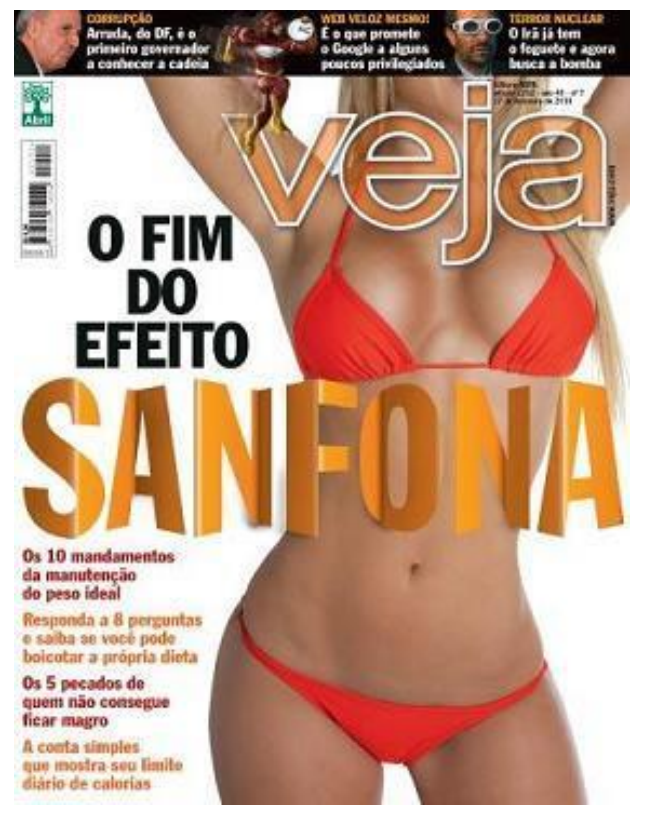

Legenda: Capa da Revista Veja, fevereiro de 2010.

Fonte: Acervo Digital Veja. Acesso em mai.2017.

Verifica-se a utilização de termos religiosos pela revista Veja para validar o discurso midiático do emagrecimento relacionado à saúde. Lemos (2005) aborda as relações de poder no âmbito religioso, elucidando que:

A religião é um sistema de símbolos que atua para estabelecer poderosas, penetrantes e duradouras disposições e motivações nos seres humanos. Ela pode tanto fornecer a explicação e a justificação das relações sociais como construir o sistema de práticas destinadas a reproduzi-las (LEMOS, 2005, p. 28). 
A religião atua como uma instância de verdade e poder por sua suposta onipresença, a partir de preceitos definidos pelas várias igrejas, tais como: ser obediente, ter fé e/ou não contestar, em meio às relações sociais. Torna-se habitual que os indivíduos recorram a ela para entender o seu lugar no mundo, a fim de compreender a si mesmos e estimar valores e comportamentos supostamente compreendidos como os mais corretos. Representações corporais veiculadas no âmbito da mídia fazem uso desses recursos retóricos - "10 mandamentos da manutenção do peso ideal" e "5 pecados de quem não consegue ficar magro" -, que são associados simbolicamente à produção de comportamentos morais, éticos e políticos, tendo em vista educar e regular a produção dos corpos.

A religião foi abordada por Foucault (1997) na chamada "genealogia do sujeito moderno" e encontra-se relacionada a estudos sobre temas como a sexualidade e a loucura. Para Foucault, o cristianismo interferiu/interfere decisivamente na educação e na constituição dos sujeitos, de modo que o poder pastoral possibilitou a salvação de quem nele crê, por meio do uso de verdades e da fé. A verdade, o saber e o poder vêm, por meio da palavra de Deus, sendo traduzidos pela Bíblia e pelos documentos da igreja, funcionando como elementos de poder e controle, o que torna o discurso religioso um poderoso recurso de captação e dominação dos sujeitos.

Como constituidora dos discursos sobre medicalização e emagrecimento, além da utilização dos termos religiosos, a revista Veja também faz uso de palavras como "arma”, "luta", "combate" e "guerra", utilizadas de forma pedagógica para vencer a obesidade, o sedentarismo e o "efeito sanfona". Palavras como "luta" e "sabotam", relacionadas a uma semântica de guerra, presentes nas capas, parecem replicar-se para atribuir sentidos completamente proibitivos ao fato de alguém viver (ou estar no mundo) com culote, celulite, barriga e/ou acima do peso.

Acresce-se, ainda, que o ramo da alimentação saudável também é apresentado pela revista como uma tática para perder medidas. Mediante os ensinamentos de receitas e dietas, o processo de emagrecimento parece facilmente alcançável. Na capa da revista Veja de novembro de 2010 (figura 5), são exibidos alimentos saudáveis, como maçã, legumes e suco verde, fazendo referência a um lanche de uma loja de fastfood de grande apreço mundial que possui alimentos industrializados e hipercalóricos, como batatas fritas e refrigerantes. 
Figura 5: Manchete "As regras boas (e viáveis) da nutrição sadia”.

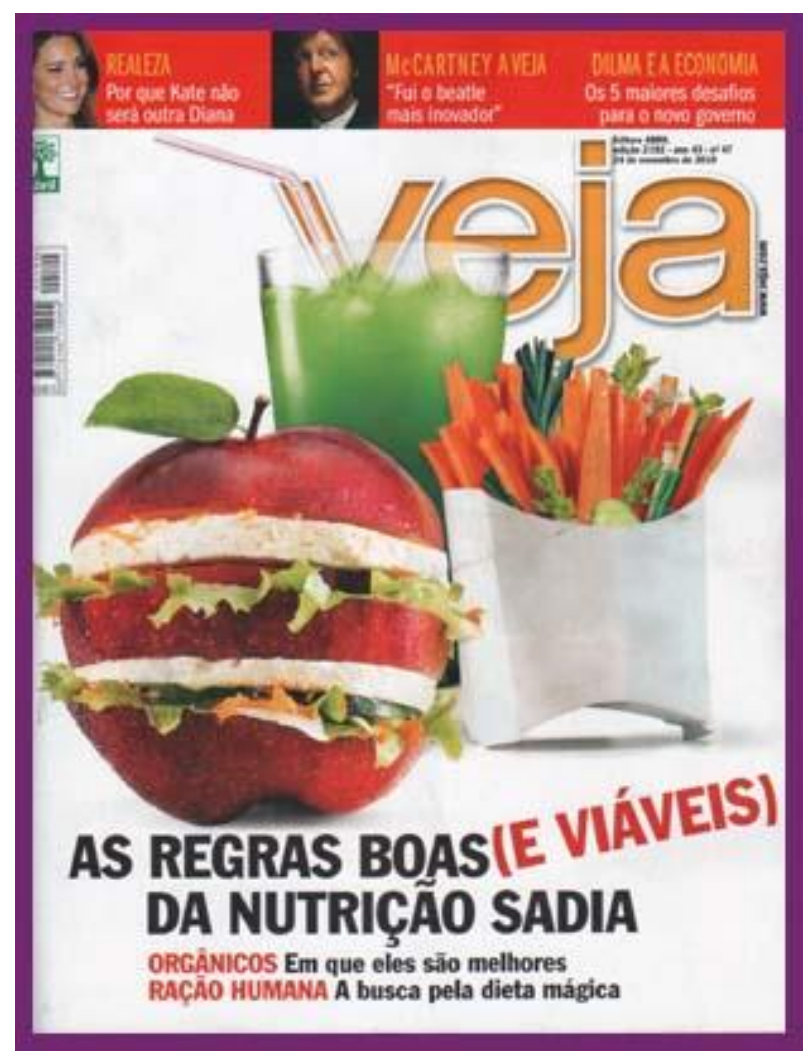

Legenda: Capa da Revista Veja, novembro de 2010.

Fonte: Acervo Digital Veja. Acesso em mai.2017.

Conforme Schwengber (2014), ao utilizar-se a imagem como recurso metodológico, estamos diante de um desafio. Justifica-se tal assertiva porque, mesmo inseridos em uma cultura da "civilização da imagem", ainda somos aprisionados à tradição da escrita, sendo esta compreendida como mais "científica" e mais "verdadeira" se comparada com a imagem, a qual é tida como mais ilusória, instintiva e imediata. Para Kossoy (2001), temos certa resistência, como acadêmicos/as, em aceitar, analisar e compreender a informação que não está nos padrões tradicionais da comunicação escrita.

Apesar desse desafio, a imagem é tão comunicativa e expressiva quanto a escrita:

A imagem - uma gravura, uma pintura, uma fotografia - revela-se de uma só vez. Permite que o olhar, delimitado somente pelas bordas, comece a vê-la a partir de qualquer ponto, vagueie por ela em diferentes direções, permaneça onde quiser, imagine. A forma imagem, com suas linhas, superfícies, perspectivas, manchas, é também a forma de pensar o que a imagem mostra. Os significados das imagens são 
também os significados de como elas se mostram. E aí as imagens tornam-se signos. Então, também se lê uma imagem. Uma imagem é um texto (ALMEIDA, 2005, p.21).

o "tratamento" do corpo (visto, portanto, desde há muito, como "doente") passou a ser necessário, conforme é possível verificar na capa e na reportagem da revista Veja de setembro de 2011 (figuras 6 e 7).

Figuras 6 e 7: Manchete "Parece Milagre" e matéria "Menos sete, menos dez, menos doze quilos".
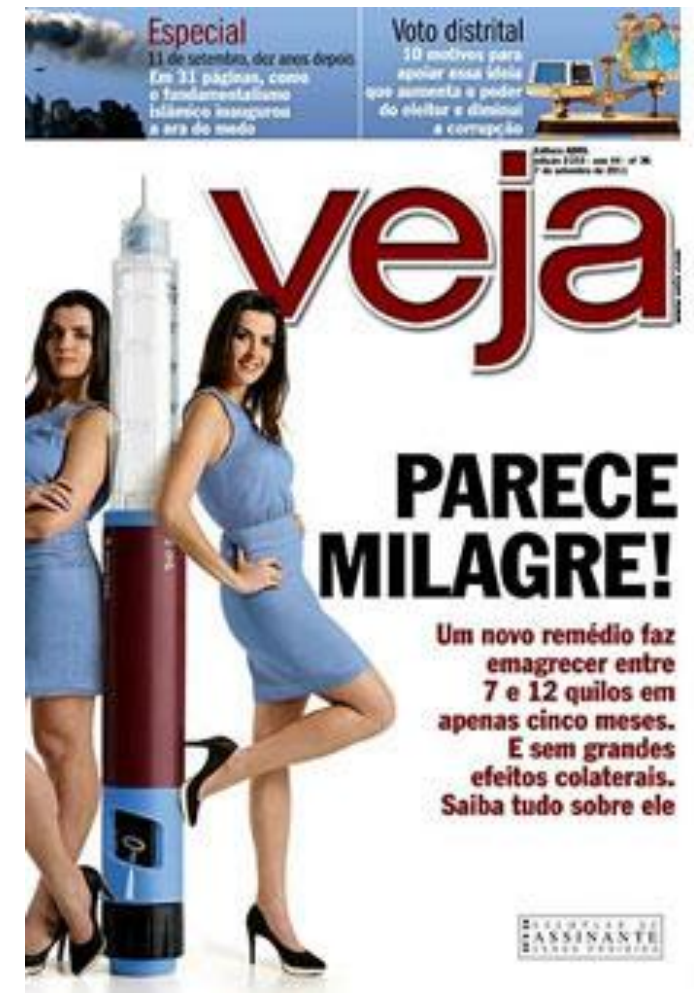

. MENOS SETE, MENOS DEZ, PARECE MENOS DOZE

Um novo remédio faz emagrecer entre 7 e 12 quilos em apenas cinco meses. E sem grandes efeitos colaterais. Saiba tudo sobre ele QUILOS!

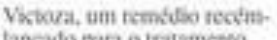
lancado pars o trasamente do diabcics, revela-se a grande

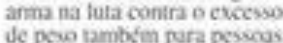
sem a doenca. Além de farer emagrecer, ele ofercece brandox Hakisiti e passugeiros cfeltos colaterais inimin-

Legenda: Capa e matéria da Revista Veja, setembro de 2011.

Fonte: Acervo Digital Veja. Acesso em mai.2017.

Diante da manchete de capa: "Parece Milagre! Um novo remédio promete o emagrecimento, entre 7 e 12 quilos, em apenas cinco meses. E sem grandes efeitos colaterais", bem como da reportagem "Menos sete, menos dez, menos doze quilos!", observa-se que medicalizar é preciso para emagrecer "sem grandes efeitos colaterais", supostamente 
proporcionando mais saúde. O medicamento abordado na reportagem é apresentado como "um remédio recém lançado para o tratamento de diabetes e revela-se a grande arma na luta contra o excesso de peso também para pessoas sem a doença. Além de fazer emagrecer, ele oferece brandos e passageiros efeitos colaterais". A foto de capa mostra duas mulheres escoradas em uma seringa, equipamento utilizado na área médica para o bombeamento de substâncias líquidas por via intravenosa. A seringa que compõe a imagem sugere a injeção como uma possibilidade para o tratamento do emagrecimento.

Verificamos, principalmente na mídia, tendências publicitárias de oferecer e suprimir, à base de medicamentos, a tristeza, a ansiedade, as alterações de humor, a hiperatividade, a obesidade, o envelhecimento, considerando estas e muitas outras condições humanas como enfermidades que necessitam ser combatidas de forma urgente. Para Conrad (2007), os seres humanos passaram a ser rotulados como portadores de patologias e responsabilizados por sua própria saúde, doença e também pela própria cura.

Meyer et al. (2006) argumentam que é a partir do pressuposto da existência de um sujeito humano potencialmente livre e autônomo que se fala das formas de viver e cuidar-se, por exemplo, tornando-se deliberadas condutas como "corretas" ou "erradas". Nessa perspectiva, o ato de fumar e/ou não controlar a ingestão de determinados alimentos pode ser compreendido como consequência da ignorância de determinados saberes, da falta de educação ou da falta de vontade do sujeito em eliminar seu vício. Assim, a saúde deverá ser concebida e exercitada de forma individual, como um processo que dependerá principalmente da sua instrução (passiva) e desejo. Esse processo tem como finalidade a mudança (imediata e unilateral) de comportamentos individuais, a partir de decisões informadas sobre a saúde, em um contexto no qual se pratica uma forma de comunicação de cunho essencialmente cognitivo e racional. 
Figura 8: Manchete "Remédios para emagrecer".

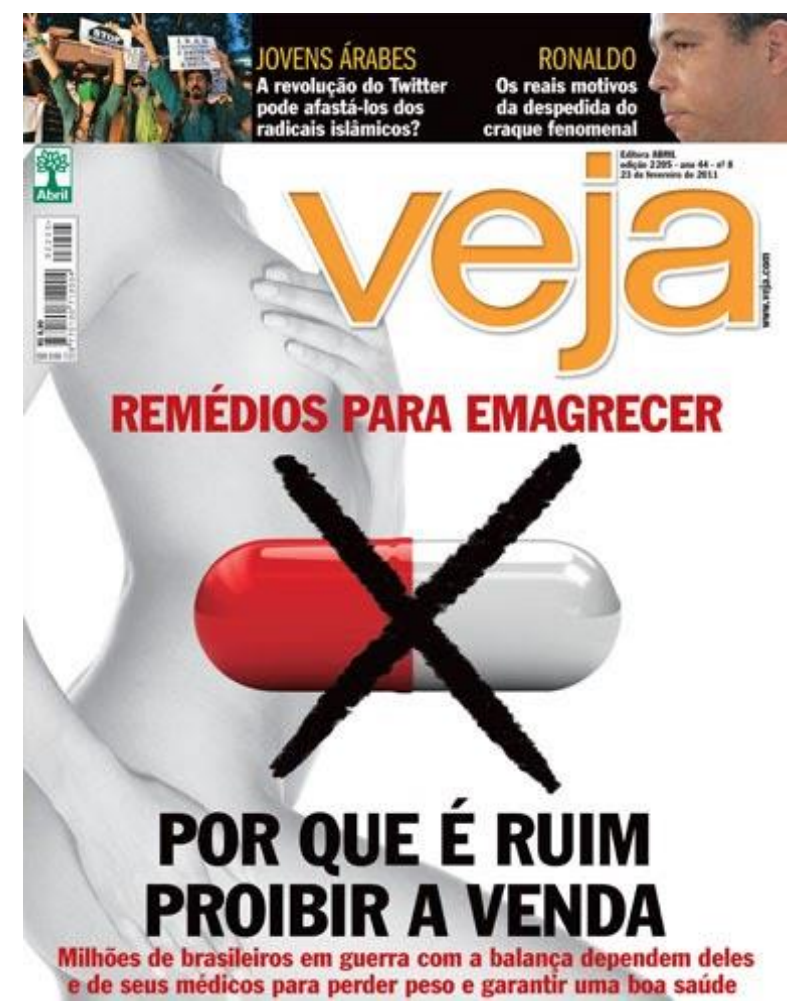

Legenda: Capa da Revista Veja, fevereiro de 2011.

Fonte: Acervo Digital Veja. Acesso mai.2017.

Na edição de fevereiro de 2011, mais uma vez é reforçada a importância da medicação no processo de emagrecimento por tratar-se de um problema de milhões de brasileiros, sendo a matéria contrária à proibição de venda (figura 8). A capa apresenta um corpo feminino, magro e nu, representado em tons de cinza claro (quase se confundindo com o fundo branco da capa). O centro da capa está composto pela manchete, em vermelho, "Remédios para emagrecer", seguida pela imagem de uma cápsula medicamentosa marcada com um "x", indicando proibição; logo abaixo, consta o complemento da manchete: "por que é ruim proibir a venda". A "guerra com a balança", segundo a revista, poderia ser ganha com o auxílio dos medicamentos, incontáveis vezes, farmacologizados ${ }^{8}$.

\footnotetext{
8 A farmacologização é um processo sociotécnico que interage com os processos de medicalização. Ela cria identidades em torno do uso de determinados fármacos e reforça a ideia de que "para cada mal há umcomprimido", levando à expansão do mercado farmacêutico além das áreas tradicionais, incluindo o uso por indivíduos saudáveis; ao enfraquecimento da predominância da profissão médica, criando relações diretas da indústria com "consumidores"; e à colonização da vida humana pelos produtos farmacêuticos (CAMARGO JR., 2013).
} 
No ano de 2015, a revista Veja sugere que o ovo se tornou um alimento aliado ao emagrecimento e à manutenção da saúde (figura 9). A capa apresenta a imagem de um ovo "sorrindo", frente a imagens de outros ovos, ora alegres, ora tristes, representando pesquisas anteriores que noticiavam possíveis malefícios e benefícios desse alimento. Além dele, o vinho tinto e o café aparecem como indicados ao consumo de quem necessita manter a saúde em dia.

Figura 9: Manchete "Ovo Vitória final”.

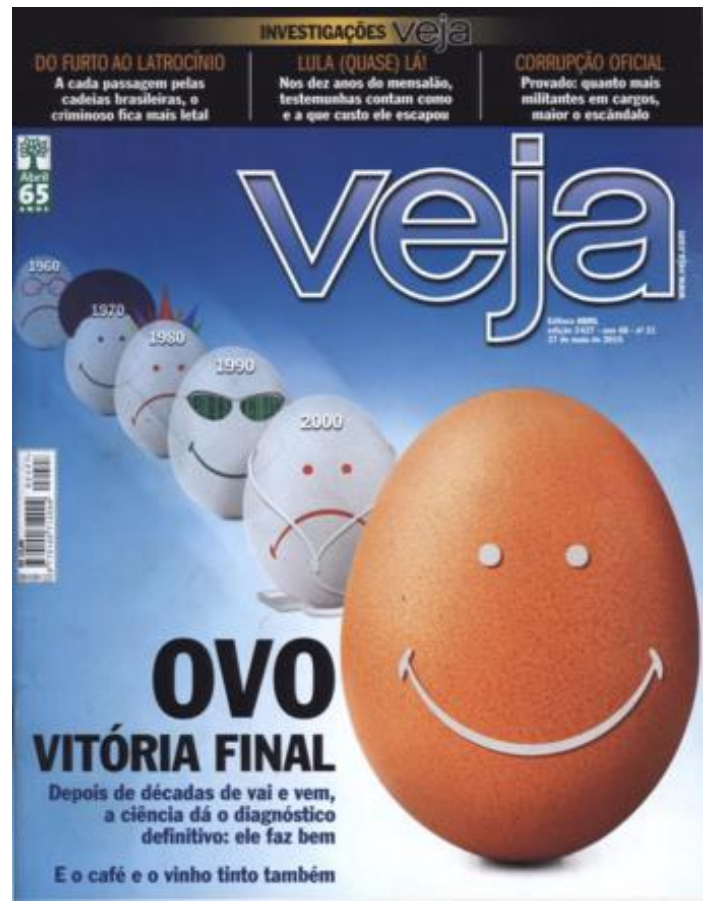

Legenda: Capa da Revista Veja, maio de 2015.

Fonte: Acervo Digital Veja. Acesso dez.2018.

Os textos escritos, articulados às imagens, fazem-nos refletir sobre as promessas que ali se constituem, sobre os locais da cultura que repetem incessantemente ensinamentos, sobre as "verdades" científicas relativas a determinados alimentos e sobre os objetivos que devem ser traçados em torno do corpo magro, representado como ícone de beleza, saúde e felicidade.

Ao partirmos da compreensão de que a mídia - especificamente, a revista Veja - atua na veiculação e na instituição de pedagogias da medicalização do corpo por meio de capas, peças publicitárias e matérias, isso significa dizer que os/as leitores/as dessa revista são 
midiaticamente ensinados/as a entenderem e controlarem os seus corpos, comportamentos, atitudes, capacidades, personalidades, etc., como potencialmente doentes e/ou necessitando de tratamento. Portanto, são sujeitos passíveis de intervenções, de procedimentos e de processos de medicalização.

\section{ALGUMAS CONSIDERAÇÕES FINAIS}

As análises evidenciam que a revista Veja atua como uma pedagogia cultural que trata de ensinar os corpos a serem magros, "saudáveis" e "belos", mesmo que para isso seja necessário o uso de medicamentos, suplementos, cosméticos ou intervenções e cirurgias plásticas. Verifica-se a produção de processos de naturalização da medicalização como forma de prevenir e evitar, a qualquer custo, a gordura, a obesidade e/ou os comportamentos que se desviam do que se institui como norma.

O emagrecimento é apresentado de forma facilitada, acessível e rápida a quem o possui como objetivo. A revista ensina diferentes formas de emagrecer com o auxílio de medicamentos e de alimentos, valendo-se, por vezes, de expressões relacionadas ao discurso religioso e/ou relativas à guerra. A lipofobia, aversão à gordura, parece um sintoma contemporâneo, frente à prevalência de conteúdo relacionado ao emagrecimento, conforme encontrado na pesquisa realizada.

Ainda, as análises sugerem que aqueles que não conseguem emagrecer ou cujos corpos se desviam dos padrões de uma normalidade utilitária estão fora do padrão, sendo vistos como os inábeis para cuidar de si, o que os faz despontar como as novas figuras de anormalidade. Obrigações e regras sobre como cuidar do corpo podem tornar-se imperativos, e a adesão (ou não) a eles pode servir como critério de avaliação do valor dos indivíduos no cenário contemporâneo.

Não buscamos desconsiderar a importância dos medicamentos em nossas vidas como estratégias para tratar e curar as doenças, porém, torna-se importante identificar e analisar alguns processos educativos que têm atuado na naturalização e no uso de medicamentos associados a um estilo de vida saudável. A partir das análises realizadas, podemos reiterar a necessidade de reconhecer e problematizar alguns dos mecanismos e processos de medicalização que incidem sobre os corpos na contemporaneidade. 


\section{REFERÊNCIAS}

ALMEIDA, M. J. Prefácio. In: SOARES, C. Imagens da educação no corpo. 3aㅗ ed.- São Paulo: Autores Associados, 2005.

ANDRADE, P. D.; COSTA, M. V. Usos e possibilidades do conceito de pedagogias culturais nas pesquisas em estudos culturais em educação. Revista Textura, Canoas, v.17, n.34, p. 48-63, 2015.

ANDRADE, P. D. Pedagogias culturais - uma cartografia das (re)invenções do conceito. Tese de Doutorado, Programa de Pós-Graduação em Educação, Universidade Federal do Rio Grande do Sul, 2016.

ANDRADE, P. D. A formação da infância do consumo: um estudo sobre crianças nos anúncios publicitários da Veja. Dissertação de Mestrado, Programa de Pós-Graduação em Educação, Universidade Federal do Rio Grande do Sul, 2010.

ANDRADE, S. S. Juventudes e processos de escolarização: uma abordagem cultural. Tese de Doutorado, Programa de Pós-Graduação em Educação, Universidade Federal do Rio Grande do Sul, 2008.

ASSINE abril.com. Disponível em: https://www.assine.abril.com.br/portal/assinar/revistaveja?origem=google_DSA_Veja_Generico\&gclid=EAIaIQobChMIoKGT9eKb7AIVigyRCh0MoQVuEAAYASAAEgI8e

_D_BwE Acesso em: 04 de out. de 2020.

BAUMAN, Z. Modernidade Líquida. Rio de Janeiro: Jorge Zahar, 2001.

BORSA, M. I. As Representações do Divórcio na Revista Veja - 1977 e 2013. Dissertação de Mestrado, Programa de Pós-Graduação em Educação, Universidade Luterana do Brasil, 2015.

BÜKER, M. P. Pedagogias midiáticas da medicalização do corpo na revista Veja. Dissertação de Mestrado, Programa de Pós-Graduação em Educação, Universidade Luterana do Brasil, 2018.

CAMARGO J. K. R. Medicalização, farmacologização e imperialismo sanitário. Cad. Saúde Pública, Rio de Janeiro, v. 29, n. 5, p. 844-846, mai. 2013. Disponível em: <http://www.scielo.br/scielo.php?script=sci_arttext \&pid=S0102311X2013000500002\&lng=en\&nrm=iso>. Acesso em 08 de maio de 2018.

CAMozzATO, V. C. Pedagogias do presente. Educação \& Realidade, Porto Alegre, v. 39, n. 2, p. 573-593, jun. 2014. Disponível em: https://seer.ufrgs.br/educacaoerealidade/article/view/34268 Acesso em 25 de agosto de 2019.

CONRAD, P. The medicalization of society. On the Transformation of Human Conditions into Treatable Disorders. Baltimore: The Johns Hopkins University Press, 2007.

COSTA, M. V. Prefácio. In: ABREU, B. F; ALMEIDA, T. S.; ROCHA, C. M. F. (Orgs.). Mídia Impressa: para além do bem e do mal. Jundiaí: Paco editorial, 2012.

CRUZ, A. M. L. Discursos que educam: representações das cotas raciais na Veja. Programa de Pós-Graduação em Educação, Universidade Luterana do Brasil, 2009.

CUNHA, M. E. B. A cultura da performatividade: narrativas sobre Educação na revista Veja. Programa de Pós-Graduação em Educação, Universidade Luterana do Brasil, 2013.

EDITORA abril. Disponível em: http://publiabril.abril.com.br/marcas/veja Acesso em 03 de abr. de 2018.

FISCHER, R. M. B. Adolescência em discurso: mídia e produção de subjetividades. Tese de Doutorado, Programa de Pós-Graduação em Educação, Universidade Federal do Rio Grande do Sul, 1996.

FISCHER, R. M. B. Televisão e educação: fruir e pensar a TV. Belo Horizonte: Autêntica, 2001. 
FISCHER, R. M. B. O estatuto pedagógico da mídia: questões de análise. Educação \& Realidade, Porto Alegre, v. 22, n. 2, p. 59-80, jul./dez.1997. Disponível em: https://seer.ufrgs.br/educacaoerealidade/article/view/71363 Acesso em 25 de agosto de 2019.

FISCHLER, C. Obeso benigno, obeso maligno. In: SANT'ANNA, D. B.(Org.). Políticas do corpo. São Paulo, estação Liberdade, 2005.

FOUCAUlT, M. A arqueologia do saber. Tradução Luiz Felipe Baeta Neves. 5 ed. Rio de Janeiro: Forense Universitária, 1997.

GIDDENS, A. Modernidade e identidade. Rio de Janeiro: Jorge Zahar Ed., 2002.

GUIZZO, B. S. “Aquele negrão me chamou de leitão": representações e práticas corporais de embelezamento na educação infantil. Tese de Doutorado, Programa de Pós-Graduação em Educação, Universidade Federal do Rio Grande do Sul, 2011.

HALL, S. A centralidade da cultura: notas sobre as revoluções culturais do nosso tempo. Educação \& Realidade, v. 22, n. 2, jul./dez. 1997.

KLEIN, C. Biopolíticas de inclusão social e produção de maternidades e paternidades para uma "infância melhor". 2010. Tese (Doutorado em Educação) - Universidade Federal do Rio Grande do Sul, Porto Alegre, 2010.

KLEIN, C. e VARGAS, J. Juventudes em campanhas de vacinação contra HPV e Meningite C - 2017 e 2018. In: CÚNICO, S. D.; COSTA, A. B. e STREY, M. N. (Orgs.). Gênero e Violência: repercussões nos processos psicossociais e de saúde. Porto Alegre. EDIPUCRS, 2019. p. 525-550.

KLEIN, C. “...Um cartão [que] mudou nossa vida”? Maternidades veiculadas/instituídas pelo Programa Nacional de Bolsa-Escola. 2003. Dissertação de Mestrado, Programa de Pós-Graduação em Educação, Universidade Federal do Rio Grande do Sul, Porto Alegre, 2003.

KOSSOY, B. Fotografia \& história. 2.ed. São Paulo: Ateliê Editorial, 2001.

LEMOS, C. T. Religião, gênero e sexualidade: o lugar da mulher na família camponesa. Goiânia: Editora da UCG, 2005.

MANIFESTO do fórum sobre medicalização da educação e da sociedade. Disponível em http://medicalizacao.org.br/manifesto-do-forum-sobre-medicalizacao-da-educacao-e-da-sociedade/ Acesso em: 25 de ago. de 2019.

MEYER, D. E. et al. "Você aprende. A gente ensina?": interrogando relações entre educação e saúde desde a perspectiva da vulnerabilidade. Cadernos de Saúde Pública, Rio de Janeiro, v. 22, n. 6, jun. 2006, p. 1335-1342.

ROSA, S. M. O. A educação escolarizada nos discursos sobre o ensino fundamental de nove anos: Isto É, Veja a reinvenção da 'nova' escola nas revistas. Dissertação de Mestrado, Programa de Pós-Graduação em Educação, Universidade Luterana do Brasil, 2008.

PETRINA, S. The medicalization of education: a historiographic synthesis. History of Education Quarterly, 2006. Disponível

em: https://www.researchgate.net/publication/230228187_The_Medicalization_of_Education_A_Historiographic_ Synthesis Acesso em 25 de agosto de 2019.

PÚBLIO, R. N. O consumo de medicamentos no Brasil: a tênue linha entre o remédio e o veneno. Disponível em: http://fenafar.org.br/fenafar/index.php/component/k2/item/7966-o-consumo-de-medicamentos-no-brasila-t\%C3\%AAnue-linha-entre-o-rem\%C3\%A9dio-e-o-veneno-por-rilke-novato* Acesso em 03 de maio de 2018.

POLI NETO, P.; CAPONI, S. N. C. La medicación de la belleza. Interface - Comunic., Saúde, Educ., v.11, n.23, p.56984 , set/dez 2007. 
SANTOS, L. H. S. Escola, currículo e medicalização do corpo. In: SANTOS, L. H. S.; SUSIN, L; DARSIE, C; ZAGO, L. F. (Orgs.). Formação de professores em um mundo em transformação. Santa Cruz do Sul: Ed. EDUNISC, 2014. p. 26-38.

SANT'ANNA, D. B. Gordos, Magros e Obesos: uma história do peso no Brasil. São Paulo: Estação Liberdade, 2016.

SCHUTZ, D; RIPOLL, D. As pedagogias da mídia e a construção da medicalização na contemporaneidade. Revista de Iniciação Científica da ULBRA, no 11, 2013.

SARLO, B. Cenas da vida pós-moderna: intelectuais, arte e videocultura na argentina. 3. ed. Rio de Janeiro: UFRJ, 1997.

SCHWENGBER, M. S. Donas de Si? A educação de corpos grávidos no contexto da Pais \& Filhos. Tese de Doutorado - Programa de Pós-Graduação em Educação, Universidade Federal do Rio Grande do Sul, 2006.

SCHWENGBER, M. S. V. O uso das imagens como recurso metodológico. In MEYER, D. E.; PARAISO, M. A. (Orgs.). Metodologias de pesquisas pós-críticas em educação. Belo Horizonte: Mazza edições, 2014, p. 261-278.

STENZEL, L. M. Obesidade: o peso da exclusão. Porto Alegre: EDIPUCRS, 2ª̃ed., 2003.

SIBILIA, P. O homem pós-orgânico - corpo, subjetividade e tecnologias digitais. Rio de Janeiro: Relume Dumará, 2002.

SIBILIA, P. O pavor da carne: risco da pureza e do sacrifício no corpo-imagem contemporâneo. Revista Famecos, no 25, Porto Alegre, dez. 2004, pp. 68-84.

VASCONCELOS, M. F. F.; ZAGO, L. F.. Mercado da/de carnes: corpos imprevistos na biopolítica. Fractal: Revista de Psicologia, v. 27, n. 3, p. 219-227, set.-dez. 2015.

VIGARELLO, G. História da Beleza. São Paulo: Ediouro, 2006.

WOODWARD, K. Identidade e diferença: uma introdução teórica e conceitual. In: SILVA, T. (org.). Identidade e diferença: a perspectiva dos estudos culturais. 7. ed. Petrópolis: Vozes, 2007.

WORTMANN, M. L. C. Análises Culturais - um modo de lidar com as histórias que interessam à educação. In: COSTA, M. V. (Org.). Caminhos Investigativos II: outros modos de pensar e fazer pesquisa em educação. Rio de Janeiro: DP\&A, 2007, pp. 71-92.

ZAGO, L. F. Os meninos - corpo, gênero e sexualidade em e através de um site de relacionamentos. Tese de Doutorado, Programa de Pós-Graduação em Educação, Universidade Federal do Rio Grande do Sul, 2013.

\section{(cc) $\mathrm{EY}_{\mathrm{B}}$}

Este trabalho está licenciado com uma Licença Creative Commons - Atribuição 4.0 Internacional. 